\title{
Physical impact of sheep grazing on arid Karoo subshrub/grass rangeland, South Africa
}

\author{
G.vanN. du Toit ${ }^{1}$, H.A. Snyman ${ }^{\#}$ \& P.J. Malan \\ Animal, Wildlife and Grassland Sciences, University of the Free State, P.O. Box 339, Bloemfontein 9300, South Africa
}

Copyright resides with the authors in terms of the Creative Commons Attribution 2.5 South African Licence.

See: http://creativecommons.org/licenses/by/2.5/za

Condition of use: The user may copy, distribute, transmit and adapt the work, but must recognise the authors and the South African Journal of Animal Science.

\begin{abstract}
Grazing levels and rotational schemes need to be tailored to each individual farm or pasture, and more studies are needed on the resilience of rangelands and on separating the effects of grazing and climate. The direct short-term impact of three rates of stocking (4, 8 and 16 Small Stock Units-SSU/ha) was quantified in terms of composition and cover of arid Nama Karoo vegetation (subshrub/grass). Mature Merino wethers grazed in one hectare plots during May in 1995 and 1996 (the plots were not subjected to grazing at any other time). The basal cover of the Karoo bushes (shrubs) showed a decrease at the highest stocking rate only, with the species Phymaspermum parvifolium the most sensitive to intensive grazing. An increase in stocking rate caused a significant decrease in both canopy cover and canopy-spread cover. The canopy cover of palatable Karoo bushes such as Felicia muricata, Salsola calluna and Walafrida geniculata decreased most. Light stocking (4 SSU/ha) was apparently the least detrimental to the vegetation composition and cover. Regardless of stocking rate, an 11-month resting period was possibly sufficient for all the vegetation parameters concerned to be fully restored after grazing took place. The rangeland rapidly reacted to rainfall as the ephemeral cover increased temporarily. The higher the stocking rate was, the greater the increase in ephemerals occurring. The ecological sustainability of the Nama Karoo ecosystem, utilised by high stocking densities, is questioned.
\end{abstract}

Keywords: Basal cover; canopy cover; canopy-spread cover; ephemerals; Karoo bushes; stocking rate

" Corresponding author. E-mail: snymanha@ufs.ac.za

${ }^{1}$ Present address: P.O. Box 94, Hanover 7005, South Africa

\section{Introduction}

Concerns about the effects of agricultural management practices on the environment have initiated interest in sustainable animal production (Snyman, 1998; Broersma et al., 1999; Hoffman \& Ashwell, 2001; Esler et al., 2006). Drought and unreliable rainfall are often blamed for agricultural declines and failures, instead of ascribing it to societal factors (Hudak, 1999). Since primary productivity is often masked by climatic fluctuations, changes in ecosystem functioning are often not detected. The slow nature of rangeland degradation makes the observation of vegetation changes difficult without prior monitoring (Van Rooyen, 1998). As rangeland managers, policy makers and the public become increasingly concerned about the sustainability of rangeland resources, soil and vegetation responses to various grazing systems (Teague \& Dowhower, 2003) need to be quantified to develop suitable grazing practices (Hoffman \& Ashwell, 2001; Holm et al., 2004; Esler et al., 2006; Hoshino et al., 2009). There has been much debate on the effects of livestock grazing on plant communities (Esler et al., 2006; Kraaij \& Milton, 2006; Anderson \& Hoffman, 2007; Du Toit et al., 2008; 2009). Vegetation composition, based on species frequency, is in general less stable at heavily grazed sites (Friedel et al., 2003). There must definitely be a threshold of vegetation change beyond which recovery does not occur (Friedel et al., 2003).

The Nama Karoo (subshrubs and grasses), where this study was conducted, is the arid south-western region of southern Africa, which is characterized by low shrubby vegetation on shallow soils. The biome occupies about $427000 \mathrm{~km}^{2}$ or $35 \%$ of the land area of South Africa and is geologically, climatically and floristically diverse (Cowling, 1986). Ranchers, rangeland scientists and ecologists agree that, at a paddock 
scale, injudicious grazing management in the Karoo can alter vegetation composition (Milton, 1994; O'Connor \& Roux, 1995; Esler et al., 2006; Kraaij \& Milton, 2006) and soil processes (Roux \& Opperman, 1986; Hoffman et al., 1999). Sparrow et al. (2003) also argued that grazing leads to a net change of resources at a paddock scale and that water and nutrients remain coupled as they move through the landscape. Such changes can exacerbate forage shortages and stock poisoning during droughts (Shearing \& Van Heerden, 1994; Esler et al., 2006). Contrasts across fences support the notion that some livestock or game ranchers in the Karoo manage their rangelands sustainably, whereas others inadvertently damage their rangeland (Milton \& Dean, 1996; Milton et al., 1998; Esler et al., 2006). The understanding of vegetation dynamics in confined plant-herbivore systems is hampered by the difficulty in uncoupling biotic determinants of vegetation changes (Dean et al., 1995; Wiegand et al., 1998; Fynn \& O'Connor, 2000; Kraaij \& Milton, 2006). Grazing levels and rotational schemes need to customize each individual farm or pasture and more studies are needed on separating the effects of grazing and climate. As drought is more of a reality than an exception in these drier areas (Snyman, 1998), the short-term planning in rangeland management is essential for sustainable animal production and will pose an increasing challenge to rangeland users as the global climate is changing (Vetter, 2009). This study is therefore aimed at the quantification of the short-term direct impact of different sheep stocking rates on the vegetation dynamics of arid subshrub/grass vegetation.

\section{Material and Methods}

The research was conducted at the research station of the Grootfontein Agricultural Development Institute, $10 \mathrm{~km}$ north-east of Middelburg in the Eastern Cape Province $\left(25^{\circ} 06^{\prime} \mathrm{E} ; 31^{\circ} 40^{\prime} \mathrm{S}\right.$, altitude 1400 $\mathrm{m}$ ), which is part of the arid region of South Africa. Rain is received almost exclusively during SeptemberNovember and March-April, with a mean annual average of $366 \mathrm{~mm}$. The study area is subjected to temperature extremes. Mean monthly maximum and minimum temperatures range from $38{ }^{\circ} \mathrm{C}$ in January to $-12{ }^{\circ} \mathrm{C}$ in June, with a mean of 150 frost days per annum (Schulze, 1979).

The study site is part of the Eastern Mixed Nama Karoo (Nama Karoo biome) (Hoffman, 1996). A complex mix of grass- and subshrub-dominated vegetation types, which are subject to dynamic changes in species composition dependent on seasonal rainfall events, occurs within this vegetation type. Common shrubs or Karoo bushes include Pentzia incana, Eriocephalus ericoides and Hermannia spp., while grasses, such as Aristida spp., Eragrostis spp. and Themeda triandra may dominate the landscape after good summer rains. This vegetation type has the highest cover of herbs of all the Nama Karoo types, as well as numerous geophytes (Hoffman, 1996).

Beaufort Group sandstones and shales dominate the landscape with the flat-topped landscape shaped by many dolerite dykes and sills (Hoffman, 1996). Soils in the study area are mostly clay loam soils of the Valsrivier Form (Zuiderzee series) (Soil Classification Working Group, 1991). The depth of the A horizon varies from 90 to $120 \mathrm{~mm}$.

The research was carried out on eight paddocks of one ha each $(108 \times 92 \mathrm{~m})$ with a western aspect and a $1 \%$ slope. The paddocks were divided into two blocks of four paddocks each, those within a block being adjacent to each other. The experimental layout is discussed in more detail by Du Toit et al. $(2008 ; 2009)$. The four treatments consisted of three different stocking rates, namely 4, 8 and 16 Small Stock Units (SSU)/ha, and a control. The stock was allowed to graze the plots for one whole month each year. Grazing was repeated at the same stocking rates in each paddock.

Mature Merino whethers were used as trial animals. The body mass of the individual animals, which were randomly allocated to the different paddocks, varied between 49.4 and $51.5 \mathrm{~kg}$. The first grazing period was 1 - 30 May 1995 and the second was 1 - 30 May 1996, a period that marks the end of the seasonal growth of both grasses and Karoo bushes (herbaceous layer). These paddocks were rested the year prior to May 1995, for the whole summer. The objective of the study was not to look at weight changes and, therefore, the animals were not weighed at the end of each season or grazing period. Grazing was not allowed in the experimental paddocks during the season preceding the trial.

In evaluating the botanical composition and cover, the basal, canopy and canopy-spread strikes were noted at the start and end of the grazing periods, for each of the two study years. The surveys were done on the same lines each year. The descending-point method (Roux, 1963) was used where basal cover was noted when the point of the spike struck the rooted area of the plant and canopy cover when it struck any part of the plant. Canopy-spread cover was noted when the spike moved through the circumference of the plant 
without piercing any plant part. A basal strike was therefore automatically noted as a canopy strike and a canopy strike as a canopy-spread strike. These terms are fully defined by Trollope et al. (1990) and Du Toit (2001). Five hundred points for each paddock were recorded where strikes or the nearest herbaceous plant, which include both annuals and perennials, were recorded for determining botanical composition and cover.

The experimental layout consisted of a split plot (before and after treatment) with four treatments (the three stocking rates and control) and two replications. The treatments and replications were randomly allocated. BMDP 2 V.9 (Dixon, 1985), set up for analysis of split plots, was used. Composition and cover were analyzed using a one-way ANOVA (Menderhall \& Sincich, 1996). The data before and after grazing, as well as differences between the two, were also analysed separately. The Number Cruncher Statistical System software package was used for this analysis (Hintze, 1997). The data for different years was analysed separately. Significant differences between treatments were determined using Tukey's test (Menderhall \& Sincich, 1996).

\section{Results}

The first grazing period (1 - 30 May 1995) was marked by little rain in the preceding three months (24\% less than the long-term mean) and no rain during that month. Though the growth activity of the vegetation was not very high, the plants were not totally dormant during this first grazing period. The second grazing period ( 1 - 30 May 1996) was marked by high rainfall (36\% above the long-term mean) in the preceding three months and light rain $(15.4 \mathrm{~mm})$ during the month. There was a high canopy-spread cover before the second grazing period, resulting in more feed available to the animals than was the case with the first grazing period (1995).

The only significant decrease $\left(F_{3,4}=18.14, P<0.01\right)$ in basal cover of the total herbaceous layer for the 1995 season, occurred at a stocking rate of $16 \mathrm{SSU} /$ ha (Figure 1). For the 1996 season grazing decreased $(P \leq 0.01)$ the basal cover for the 4,8 and $16 \mathrm{SSU} /$ ha stocking rates. The greatest decrease in basal cover occurred at a stocking rate of $16 \mathrm{SSU} / \mathrm{ha}$, when it decreased in 1995 and 1996 with $44 \%\left(F_{3,4}=14.14\right.$, $P<0.01)$ and $39 \%\left(F_{3,4}=16.12, P<0.01\right)$, respectively, due to grazing. As expected, a slight increase in basal cover occurred with no grazing, viz. 11 and 3\% for the 1995 and 1996 seasons, respectively. In contrast to the decrease in basal cover of the annual/poor perennial grasses (Aristida congesta, Chloris virgata, Schismus fasiculatus, Tragus koelerioides and T. racemosa), the basal cover of the bushes was least influenced by grazing. The basal cover of the Karoo bushes decreased only at the highest stocking rate. Ephemerals occurred only during the 1996 season before grazing.

During the 1995 season the basal cover of especially $T$. koelerioides, decreased the most, from 0.8 to $0.2 \%(P<0.01)$. due to grazing at a stocking rate of $16 \mathrm{SSU} / \mathrm{ha}$, and from 1.0 to $0.6 \%$ for the 1996 season. The basal cover of the grasses decreased $(P<0.01)$ for the 1995 and 1996 seasons at a stocking rate of 16 SSU/ha with an average of 1.4 to $0.8 \%$. The basal cover of the Karoo bush, Phymaspermum parvifolium, decreased the most $(P<0.01)$ at stocking rate increase.

Grazing decreased $(P \leq 0.01)$ both canopy cover and canopy-spread cover of the herbaceous layer for the 1995 season at a stocking rate of 4 SSU/ha, which was not the case in the 1996 season (Figure 1). Again, the highest stocking rate $(16 \mathrm{SSU} / \mathrm{ha})$ decreased $(P<0.01)$ the cover the most in both seasons: For example, grazing decreased the canopy cover and canopy-spread cover at the $16 \mathrm{SSU} /$ ha stocking rate during the 1995 season with $53 \%\left(F_{3,4}=16.12, P<0.01\right)$ and $63 \%\left(F_{3,4}=17.15, P<0.01\right)$, respectively. The canopy cover and canopy-spread cover of the bushes were mostly decreased $(P<0.01)$ by grazing compared to the control. As expected, the canopy and canopy-spread covers of both grasses and Karoo bushes remained reasonably constant $\left(F_{3,4}=5.12, P>0.05\right)$ with a slight increase during the two seasons. Again, most of the ephemerals were observed just before the second grazing in the 1996 season.

The canopy cover of the grass, Eragrostis obtusa, decreased the most $\left(F_{1,6}=16.96, P<0.01\right)$ at a stocking rate of $16 \mathrm{SSU} / \mathrm{ha}$, from 6.2 to $3.6 \%$ during the 1996 season. The canopy cover of the palatable Karoo bush, Felicia muricata, decreased most $\left(F_{1,6}=17.15, P<0.01\right)$ with grazing for this season, from an average of 10.0 to $5.6 \%$; 6.3 to $3.0 \%$ and 11.6 to $2.4 \%$ for the 4,8 and $16 \mathrm{SSU} /$ ha stocking rates, respectively. Both the canopy and canopy-spread cover of another two palatable Karoo bushes, Salsola calluna and Walafrida geniculata, also decreased $\left(F_{1,6}=7.14, P<0.05\right)$ with grazing, but to a lesser extent than Felicia muricata. 

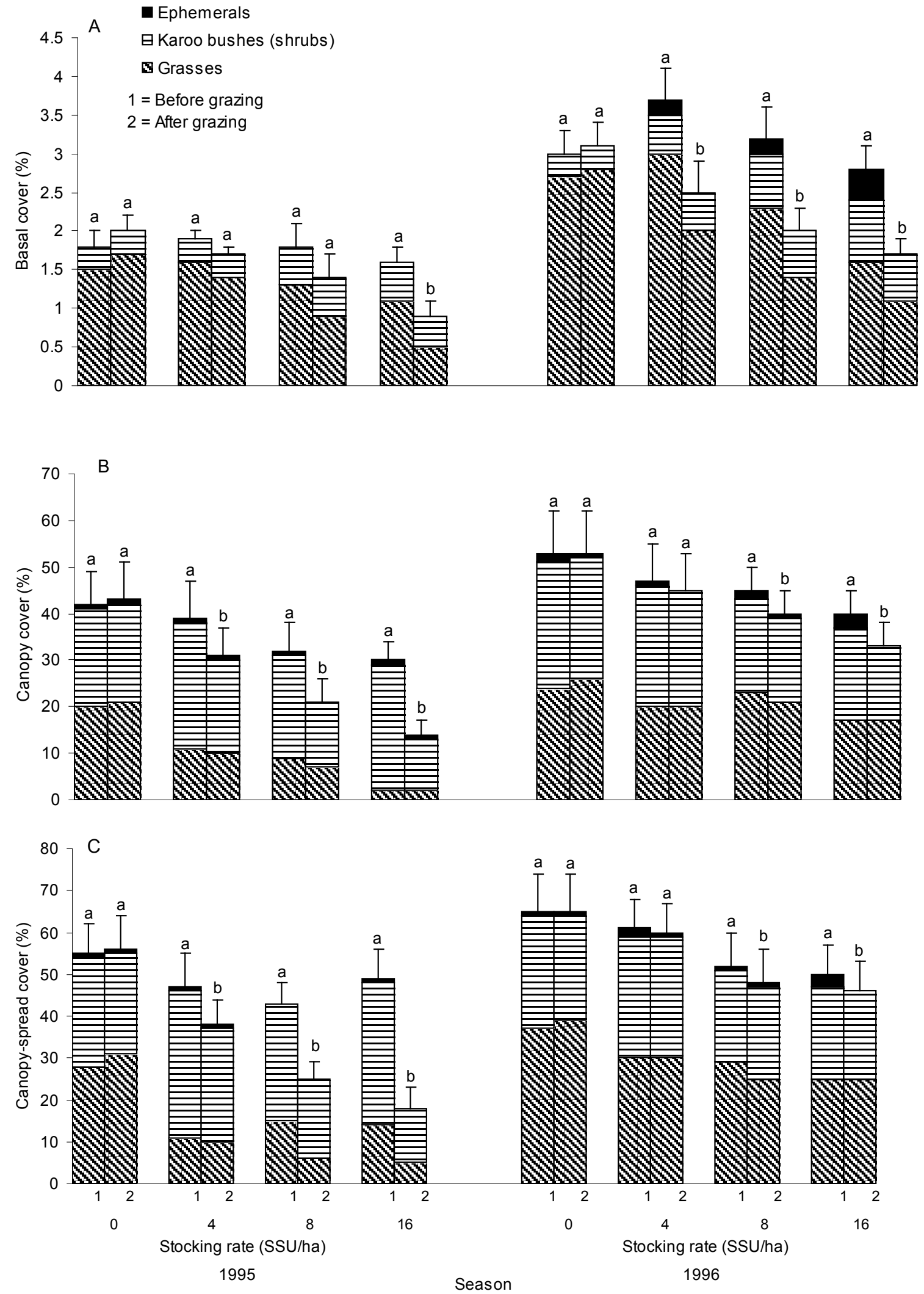

Figure 1 Percentage basal cover (A), canopy cover (B) and canopy-spread cover (C) of the herbaceous species (grasses, Karoo bushes (shrubs) and ephemerals), for the different stocking rates, measured before and after grazing during the 1995 and 1996 seasons. Means \pm SE $(\mathrm{n}=4)$ with different superscripts differ significantly $(P \leq 0.01)$ within a stocking rate. 
Within a grazing treatment, the cover (basal, canopy and canopy-spread) drastically increased from the 1995 to the 1996 season. This increase can largely be attributed to the above-average rainfall preceding the 1996 season, drastically stimulating the ephemerals. Twice the normal amount of rainfall occurred from September 1995 to January 1996. Unfortunately, the ephemerals are only temporary and dependent on climate. For example, the canopy-spread cover of the ephemerals only increased (before grazing of the 1995 season to before grazing in 1996), with an average of 0.6 to $1.4 \% ; 0.6$ to $2.2 \% ; 0.8$ to $3.0 \%$ and from 1.2 to $4.2 \%$ for the stocking rates of $1,4,8$ and $16 \mathrm{SSU} / \mathrm{ha}$, respectively. The total canopy and canopy-spread covers increased (before grazing of 1995 up to the grazing of the 1996 season), with an average of 43 to $53 \%$ and from 56 to $65 \%$, respectively. Even more conspicuous was that, the higher the stocking rate, the greater the increase in cover from the 1995 to the 1996 seasons, with an increase which was even more than that of ungrazed rangeland. This was mainly caused by an increase in annual pioneer grasses such as Chloris virgata, Enneapogon desvauxii, Schismus fasiculatus, Tragus racemosa; perennial ephemerals such as Galenia sarcophylla, Geigeria filifolia, Hermannia cococarpa, H. pulverata, Indigofera alternans as well as annual ephemerals such as Arctotheca calendula, Chenopodium glaucum, Convolvulus arvensis, Erodium cicutarium and Tribulus terrestris, which were absent from the 1995 survey. The less palatable Karoo bushes, Talinum caffrum and Pterothrix spinescens, only occurred after the 11-month resting period.

\section{Discussion}

This study showed that an increase in stocking rate in the short term resulted in an almost linear decrease in canopy and canopy-spread cover. This agrees with the findings of a few other researchers who reported a decrease in cover due to high stocking rates in semi-arid rangelands (Roux, 1967; Friedel, 1991; O'Connor, 1995; Mworia et al., 1997; Ingram, 2003; Wood et al., 2008; Hoshino et al., 2009), while others have found either a positive or inconclusive relationship (Belsky, 1992; O'Connor, 1994). A further increase in stocking rate for the same grazing periods, as applied in this study, should lead to a still higher decrease in canopy and canopy-spread cover. The decrease in basal cover may possibly not always be significant, as basal cover is the most constant parameter of this vegetation. The higher the stocking rate, the higher the decrease in canopy and canopy-spread cover and the longer resting period is needed for rangeland to recover (Milton et al., 1998; Sparrow et al., 2003; Tongway et al., 2003; Kraaij \& Milton, 2006). According to Mworia et al. (1997), the herbaceous biomass and cover in heavily grazed semi-arid rangeland did not recover after a two-year resting period. Various researchers found that too much severe defoliation with relatively short resting periods in between, are detrimental to vegetation cover and dry matter production (Du Preez, 1972; Hobson \& Sykes, 1980; Van der Westhuizen, 1980). In any grazing study, the dynamic nature of plant responses to grazing needs to be considered and in particular the process of compensatory growth, or regrowth of grazed foliage (McNaughton et al., 1996; Ingram, 2003). Unfortunately, the recovery periods necessary for the different grazing treatments were not investigated in this study.

From this study it can generally be concluded that at a higher stocking density, a shorter grazing period rather than a lower density is important to limit the degree of defoliation. In resilient landscapes, grazing trials of even a 10-year duration may be too short to provide reliable estimates of sustainable rates of stocking (Holm et al., 2004). Bisigato et al. (2008) highlighted the importance of including sites under a wide range of grazing pressure/disturbance in determining the relationships between grazing pressure and the conservation of soil resources. Heavy grazing can also result in the same floristic changes as those brought about by nitrogenous fertilizers (Van Rensburg, 1939). This is because grazing led to the more rapid cycling of nitrogen which increased the proportion of plant-available forms (Roux, 1979).

The considerably high palatability of the three Karoo bushes, namely Salsola calluna, Walafrida geniculata and Felicia muricata, and therefore their good utilization, can possibly be the main reason for this significantly lower canopy and canopy-spread cover after grazing. Holm et al. (2004) also concluded that both average primary productivity and the potential for secondary productivity were reduced with heavy grazing. The duration of the resting period for recovery of rangeland will be determined by the degree of defoliation, as well as the climatic condition during the resting period (Snyman, 1999). In the case of this study an 11-month resting period under these specific climatic conditions is possibly sufficient for all the vegetation parameters concerned to be fully restored. In this case, the contributing factor, which must not be disregarded, was the good rainfall occurring during September 1995 to January 1996. The rainfall in these five months was more than twice that of the long-term average expected for these months. This favourable climatic condition caused the vegetation of the study area to have a considerably good cover after the resting 
period following the first grazing period. Unfortunately, to a large extent, temporary ephemerals reacted most favourably to the spring rainfall. The higher the stocking rate was, the greater was the increase in ephemerals occurring. Thurow et al. (1988) also reported that high stocking rates caused a greater dominance of seasonal short-grasses and forbs compared to low stocking rates on semi-arid rangeland. Marked changes in floristic composition can therefore take place in areas of lower rainfall in response to not only grazing pressure, but also variation in rainfall (O'Connor \& Bredenkamp, 1997). In some regions and climates, grazing effects remain difficult to identify due to the naturally spatial and temporal variation in resource availability and, consequently, plant growth and diversity (Ingram, 2003). Quantifying plant responses to defoliation at either the plant or landscape level can lead to dramatically different interpretations (Ingram, 2003).

\section{Conclusions}

There is a controversy among farmers and researchers on the advantages and disadvantages of high grazing pressure, as well as of its short and long-term impact on the sustainable functioning of the rangeland ecosystem. In this study, an increase in stocking rate taking place during the short-term lead to an almost linear decrease in canopy and canopy-spread cover. This study does not lend itself to concrete recommendations regarding stocking rate and grazing systems. Factors like the influence of the length of the grazing period on the parameters investigated in this study, the restoration time necessary after grazing took place and the effect on other soil forms, are questions which will first have to be answered in future. A very good cover, after only 11 months of rest, did occur and was also accompanied by above-average follow-up rainfall. Unfortunately mainly annual pioneer grasses and ephemerals appeared due to the favourable climatic conditions and rest. The study area is characterized by ephemerals which appear rapidly in favourable climatic conditions. The study, therefore, showed that the dynamics of arid rangelands depended mainly on two factors, viz. the level of grazing intensity and the variation in rainfall.

\section{References}

Anderson, P.M.L. \& Hoffman, M., 2007. The impacts of sustained heavy grazing on plant diversity and composition in lowland and upland habitats across the Kamiesberg mountain range in the Succulent Karoo, South Africa. J. Arid Environ. 70, 686-700.

Belsky, J., 1992. Effects of grazing competition, disturbance and fire on species composition and diversity in grassland communities. J. Veg. Sci., 3, 187-200.

Bisigato, A.J., Laphitz, R.M.L. \& Carrera, A.L., 2008. Non-linear relationships between grazing pressure and conservation of soil resources in Patagonian Monte shrublands. J. Arid Environ. 72, 1464-1475.

Broersma, K., Krysic, M., Thompson, D.J. \& Bornke, A.A., 1999. Effect of long-term grazing on soil quality in southern British Columbia. Proc. VI Int. Rangl. Cong. Townsville, Australia 1, 114-115.

Cowling, R.M., 1986. A description of the Karoo Biome Project. South African National Scientific Programmes Report 122, Pretoria: Foundation for Research Development. pp. 1-43.

Dean, W.R.J., Milton, S.J. \& du Plessis, M.A., 1995. Where, why and to what extent have rangelands in the Karoo, South Africa, desertified? Environ. Mon. Assessment 37, 103-110.

Dixon, W.J., 1985. BMDP Statistical Software Manual. University of California Press. Berkley, Los Angeles, London.

Du Preez, C.M.R., 1972. Die produksiepotensiaal van Karooveld: Groei en opbrengs van Karoobossies en reaksie op snoei. Final Report K-Gf 109/1. Department of Agriculture (Karoo Region) Middelburg, C.P. South Africa (Unpublished).

Du Toit, G.vanN., Snyman, H.A. \& Malan, P.J., 2008. Physical impact of grazing by sheep in the Nama Karoo subshrub/grass rangeland of South Africa on litter and dung distribution. S. Afr. J. Anim. Sci. 38, 326-330.

Du Toit, G.vanN., Snyman, H.A. \& Malan, P.J., 2009. Physical impact of grazing by sheep on soil parameters in the Nama Karoo subshrub/grass rangeland of South Africa. J. Arid Environ. 73, 804-810.

Du Toit, P.C.V., 2001. The relation between canopy spread cover and the aboveground available phytomass of Nama Karoo subshrubs and grasses. Afr. J. Range For. Sci. 18, 143-146.

Esler, K.J., Milton, S.J. \& Dean, W.R.J., 2006. Karoo veld - Ecology and Management. Briza Publishers, South Africa. pp. 214. 
Friedel, M.H., 1991. Range condition assessment and the concept of thresholds: a viewpoint. J. Range Mgmt. 44, 422-426.

Friedel, M.H., Sparrow, A.D., Kinloch, J.E. \& Tongway, D.J., 2003. Degradation and recovery processes in arid grazing lands of central Australia. Part 2: vegetation. J. Arid Environ. 55, 327-348.

Fynn, R.W.S. \& O'Connor, T.G., 2000. Effect of stocking rate and rainfall on rangeland dynamics and cattle performance in a semi-arid savanna, South Africa. J. Appl. Ecol. 37, 491-507.

Hintze, J.L., 1997. Number Cruncher Statistical System, Kaysville, Utah, USA.

Hobson, F.O. \& Sykes, E., 1980. Defoliation frequency with respect to three Karoo Bush species. Karoo Agric. 1, 9-11.

Hoffman, M.T., 1996. Eastern Mixed Nama Karoo, pp. 55. In: Vegetation of South Africa, Lesotho and Swaziland. Eds Low, A.G. \& Rebelo, A.B., Department of Environmental Affairs and Tourism, Pretoria, South Africa. pp. 85.

Hoffman, M.T. \& Ashwell, A., 2001. Nature divided land degradation in South Africa. University of Cape Town Press, Cape Town, South Africa. pp. 168.

Hoffman, M.T., Cousins, B., Meye, R.T., Petersen, A. \& Hendricks, H., 1999. Historical and contemporary land use and the desertification of the Karoo. In: The Karoo: Ecological Patterns and Processes. Eds Dean, W.R.J. \& Milton, S.J., Cambridge University Press, Cambridge. pp. 257-273.

Holm, A.McR., Watson, I.W., Speijers, E.J., Allen, R.J., Eliot, G.J., Shackleton, K.R. \& Stretch, J.K., 2004. Loss of patch-scale heterogeneity on secondary productivity in the arid shrubland of Western Australia. J. Arid Environ. 61, 631-649.

Hoshino, A., Yoshihara, Y., Sasaki, T., Okayasu, T., Jamsran, U., Okuro, T. \& Takeuchi, K., 2009. Comparison of vegetation changes along grazing gradients with different numbers of livestock. J. Arid Environ. 73, 687-690.

Hudak, A.T., 1999. Rangeland mismanagement in South Africa: Failure to apply ecological knowledge. Human Ecol. 27, 55-78.

Ingram, L.J., 2003. Growth, nutrient cycling and grazing of three perennial tussock grasses of the Pilbare region of NW Australia. PhD thesis, University of Western Australia Perth, Australia. pp. 280.

Kraaij, T. \& Milton, S.J., 2006. Vegetation changes (1995-2004) in semi-arid Karoo shrubland, South Africa. Effects of rainfall, wild herbivores and change in land use. J. Arid Environ. 64, 174-192.

McNaughton, S.J., Milchunas, D.G. \& Frank, D.A., 1996. How can net primary productivity be measured in grazed ecosystems? Ecol. 77, 974-977.

Mendenhall, W. \& Sincich, T., 1996. Principles of experimental design. A second course in Statistics. $5^{\text {th }}$ Edition. Prentice-Hall Inc., New Jersey. pp. 582-595.

Milton, S.J., 1994. Growth, flowering and recruitment of shrubs in grazed and in protected rangeland in the arid Karoo, South Africa. Vegetatio 111, 17-27.

Milton, S.J. \& Dean, W.R.J., 1996. Karoo Veld: Ecology and Management. Pretoria: ARC-Range and Forage Institute, South Africa.

Milton, S.J., Dean, W.R. \& Ellis, R.P., 1998. Rangeland health assessment: a practical guide for ranchers in arid Karoo shrublands. J. Arid Environ. 39, 253-265.

Mworia, J.K., Mnene, W.M., Musimbi, D.K. \& Reid, R.S., 1997. Resilience of soil and vegetation subjected to different grazing intensities in a semi-arid rangeland of Kenya. Afr. J. Range For. Sci. 14, 26-31.

O'Connor, T.G., 1994. Composition and population responses of an African savanna grassland to rainfall and grazing. J. Appl. Ecol. 31, 155-171.

O'Connor, T.G., 1995. Transformation of a savanna grassland by drought and grazing. Afr. J. Range For. Sci. 12, 53-60.

O’Connor, T.G. \& Bredenkamp, G.J., 1997. Grassland. In: Vegetation of southern Africa. Eds Cowling, R.M., Richardson, D.M. \& Pierce, S.M., Cambridge University Press, Cambridge.

O'Connor, T.G. \& Roux, P.W., 1995. Vegetation changes (1949-71) in a semi-arid, grassy dwarf shrublands in the Karoo, South Africa: influence of rainfall variability and grazing by sheep. J. Appl. Ecol. 32, 612-626.

Roux, P.W., 1963. The descending-point method of vegetation survey: A point sampling for surveying of semi-open grassland and Karoo vegetation in South Africa. S. Afr. J. Agric. Sci. 6, 273-288.

Roux, P.W., 1967. Die onmiddellike uitwerking van intensiewe beweiding op Karooveld. Proc. Grassld. Soc. South. Afr. 2, 83-90. 
Roux, P.W., 1979. Elements of the trampling factor in stock. Karoo Agric. 1, 9-12.

Roux, P.W. \& Opperman, D.P.J., 1986. Soil erosion. Part 1 - physical environment, South African National Scientific Programmes Report 124. In: The Karoo Biome: a preliminary synthesis. Eds Cowling, R.M., Roux, P.W. \& Pieterse, A.J.H., Pretoria: Foundation for Research Development, South Africa.

Schulze, E.R., 1979. Climate of South Africa. Part 8. General Survey, Weather Bureau, Pretoria, South Africa. p. 158.

Shearing, D. \& van Heerden, K., 1994. Karoo: South African wild flower guide 6. Cape Town: Botanical Society, South Africa.

Snyman, H.A., 1998. Dynamics and sustainable utilization of the rangeland ecosystem in arid and semi-arid climates of southern Africa. J. Arid Environ. 39, 645-666.

Snyman, H.A., 1999. Short-term effects of soil water, defoliation and rangeland condition on productivity of a semi-arid rangeland in South Africa. J. Arid Environ. 43, 47-62.

Soil Classification Working Group, 1991. Soil Classification: A Taxonomic System for South Africa. Department of Agriculture Development, Pretoria, South Africa, pp. 262.

Sparrow, A.J., Friedel, M.H. \& Tongway, D.J., 2003. Degradation and recovery processes in arid grazing lands of central Australia. Part 3: implications at landscape scale. J. Arid Environ. 55, 349-360.

Teague, W.R. \& Dowhower, S.L., 2003. Patch dynamics under rotational and continuous grazing management in large, heterogeneous paddocks. J. Arid Environ. 53, 211-229.

Thurow, T.L., Blackburn, W.H. \& Taylor, C.A., 1988. Some vegetation responses to selected livestock grazing strategies. J. Range Mgmt. 41, 108-114.

Tongway, D.J., Sparrow, A.D. \& Friedel, M.H., 2003. Degradation and recovery processes in arid grazing lands of central Australia. Part 1: Soil and land resources. J. Arid Environ. 55, 301-326.

Trollope, W.S.W., Trollope, L.A. \& Bosch, O.J.H., 1990. Veld and pasture management terminology in Southern Africa. J. Grassld. Soc. South. Afr. 7, 52-61.

Van der Westhuizen, F.G.F., 1980. Invloed van snoei op fotosintese, reserwestatus en droëmateriaalproduksie van Ehrharta calcycina en Osteospermum sinuatum. $\mathrm{PhD}$ thesis, University of Stellenbosch, South Africa.

Van Rensburg, H.J., 1939. A further contribution to the ecology of the highveld grassland at Frankenwald. S. Afr. J. Sci. 36, 238-245.

Van Rooyen, A.F., 1998. Combating desertification in the southern Kalahari: connecting science with community actions in South Africa. J. Arid Environ. 39, 285-297.

Vetter, S., 2009. Drought, change and resilience in South Africa's arid and semi-arid rangelands. S. Afr. J. Sci. 105, 29-34.

Wiegand, T., Jeltshc, F., Bauer, S. \& Kellner, K., 1998. Simulation models for semi-arid rangelands of southern Africa. Afr. J. Range For. Sci. 15, 48-60.

Wood, K., Rubio, H. \& Wood, C., 2008. Rangeland Management and Hydrology. Proc. XXI Int. Grassld. Cong. and VII Int. Rangeld. Cong., Hohhot, China 1, 809-812. 